\title{
SYSTEMIC FUNCTIONAL LINGUISTIC GENRE PEDAGOGY (SFL GP) IN A TERTIARY EFL WRITING CONTEXT IN INDONESIA
}

\author{
Emi Emilia \\ (emi.emilia.upi@gmail.com) \\ Fuad Abdul Hamied \\ (fuadah@indo.net.id) \\ Indonesia University of Education \\ Jl. Dr, Setiabudi No. 229, Jawa Barat, Indonesia
}

\begin{abstract}
This article reports on the results of a study aiming to investigate whether systemic functional linguistic genre pedagogy (SFL GP) can help students develop their writing ability in English and the students' opinions about the teaching program using SFL GP. The study was conducted in one semester with 19 student teachers taking a writing course on argumentative texts, in the English Department at a state university in West Java, Indonesia. The texts in focus were Exposition, Discussion and Response to Literary Works, but in the interests of space, the article will centre around Exposition. The study used a qualitative case study research design with data collected from participant observations for 16 meetings, analysis of students' texts collected over the program, and questionnaires distributed at the conclusion of the program. The results indicate that despite some aspects that still need improvement, SFL GP can generally help students develop their writing ability. Observation data show students' writing skill improvement supported by students' texts which depicts good control of the schematic structure and linguistic features of the texts in focus. Finally, questionnaire data reveal students' consciousness of improved writing skill and positive responses to each activity in the program. Based on the results of the study, it is recommended that SFL GP be implemented in other contexts in Indonesia and other countries.
\end{abstract}

Keywords: genre pedagogy, writing, argumentative texts

DOI: http://dx.doi.org/10.15639/teflinjournal.v26i2/155-182 
Systemic functional linguistic genre pedagogy (henceforth SFL GP) has formally existed in Indonesia since 2004 (Indonesian Ministry of National Education, 2004), when the government released a curriculum for teaching English in Indonesian schools, inspired by Australian genre pedagogy. Genre pedagogy has grown from a theory of how speakers use language in social life (a functional theory of language), and specifically out of the systemic functional linguistic (SFL) theory (Rose \& Martin, 2012; see also Christie, 2012; Derewianka \& Jones, 2012; Joyce \& Feez, 2012, Hertzberg, 2012). Genrebased research and pedagogy are now well established in many parts of the world, including Australia, China, Singapore, Hong Kong, Vietnam, a number of European nations including France, Germany, Denmark, Sweden, and several South American countries such as Brazil and Argentina (Emilia, Christie, \& Humphrey, 2012), and now in Indonesia.

- Can SFL GP help students develop their writing ability in English, especially writing argumentative texts?

- What are the students' opinions about the teaching program using SFL GP?

SFL

SFL is a social theory of language, also called the theory of language in context, and its basic principles are summarised in Table 1.

Table 1. Key Aspects of Systemic Functional Linguistics (Adapted from Feez, Iedema \& White, as cited in Emilia, 2010, p. 11)

\begin{tabular}{ll}
\hline $\begin{array}{l}\text { Language as a re- } \\
\text { source for meaning }\end{array}$ & $\begin{array}{l}\text { Language is a system of choices. Language users choose } \\
\text { from the resources of the language system to make meanings } \\
\text { which are appropriate to the social context, which constrains } \\
\text { the choices that are made from the linguistic system. }\end{array}$ \\
\hline $\begin{array}{l}\text { Texts as the basic unit } \\
\text { of meaning }\end{array}$ & $\begin{array}{l}\text { Language users communicate in texts, not isolated words or } \\
\text { sentences. Texts, no matter how long or short, are the basic } \\
\text { units of meaning in language. The study of language should } \\
\text { look at the structure and organisation of language in texts - } \\
\text { not at isolated and idealised extracts. }\end{array}$ \\
\hline $\begin{array}{l}\text { Systematic relation- } \\
\text { ship between text and } \\
\text { context. }\end{array}$ & $\begin{array}{l}\text { All language occurs in social contexts. There is a symbolic } \\
\text { relationship between language and the social context in } \\
\text { which it is used. Social contexts exert influence on the } \\
\text { choices that are made from the linguistic system and lan- }\end{array}$ \\
\hline
\end{tabular}


guage itself helps shape social contexts. SFL gives a detailed systematic account of the relationship between text and context.

Functional labels $\quad$ SFL identifies and labels elements of text according to the function they perform in making meaning. Terms such as participant, process, and circumstances are functional labels.

All the basic points of SFL have been summarized by Eggins, who notes:

... common to all systemic linguists is an interest in how people use language with each other in accomplishing everyday social claims about language: that language use is functional; that its function is to make meanings; that these meanings are influenced by the social and cultural context in which they are exchanged and that the process of using language is a semiotic process, a process of making meanings by choosing (1994, p. 2).

Apart from the basic points above, SFL emphasizes that language has three general functions - the interpersonal function, to do with the relationships that are enacted by language, known as the tenor of social relations (who is involved), the ideational function, to do with the experiences that are construed by language, known as the field of the experience, and the textual function (to do with the role that language plays in the context, how language works to create connected and coherent discourse, known as the mode of communication, such as speaking or writing (Rose \& Martin, 2012; see also Derewianka \& Jones, 2012; Joyce \& Feez, 2012; Rowsell, 2013; Emilia, 2014). The term mode has also been extended to nonverbal elements and thus the term multimodality is now frequently used (Rowsell, 2013).

Each function is realised through different systems of grammar. The experiential metafunction is realised through the Transitivity system, the textual metafunction through the Theme patterns of grammar and the interpersonal metafunction through the Mood patterns of the grammar (Eggins, 1994). How these systems of grammar work in creating a text was also focused in this study. 


\section{SFL GP}

SFL GP has been developed mainly in Australia and the term genre in SFL GP is considered as text types (Martin \& Rose, 2008) and "the ways that we get things done through language - the ways we exchange information and knowledge and interact socially" (Callaghan, Knapp, \& Knobble, 1993, p. 193).

The term genre comes from the Latin 'genus' meaning a class or category and contains the idea of conventions which construe the different social purposes of text types and indicate different ways of reading and composing literary and factual texts (McDonald, 2013, p. 8). Based on social purposes of genres, genre theorists within an Australian SFL perspective argue that there are at least eight prototypical genres: Recount, Report, Explanation, Exposition, Discussion, Procedure, Narrative, News Story (see Christie \& Derewianka, 2008; Martin \& Rose, 2008). However, this categorisation is not fixed and in some cases there is a possibility that different genres are integrated and synthesised to create a macro genre (Martin \& Rose, 2008). "Genre conventions change in different contexts and over time" (Winch et al., 2010, cited in McDonald, 2013, p. 8).

SFL GP aims to develop "a literacy pedagogy that can empower students to gain access to educational discourses of the kind that they may otherwise not become familiar with in their life, to acquire and critique the genres required for success in schooling, in employment, and in the community" (MackenHorarik, 2002, pp. 44-45). SFL GP stresses several basic principles and each basic principle will be discussed below based on the work of Joyce \& Feez, 2012; Droga \& Humphrey, 2003; Derewianka \& Jones, 2012; Rose \& Martin, 2012.

\section{Principle 1: Language is functional}

A functional model of language explains how the purpose and context of a text (a unit of written or spoken language) affects the language features used. Two major factors affect the language features of a particular text: genre (text types) and register (field, mode, and tenor), as discussed above. 


\section{Principle 2: Learning is a social activity}

Learning is a social activity and the outcome of collaboration between student and teacher and students learn under the guidance of the teacher in apprenticeship, with the students as an apprentice and the teacher in the authoritative role of expert on language system and function (Joyce \& Feez, 2012). Students' language development, it is said, "does not take place naturally, rather, it occurs in social contexts, usually those of schooling and other educational institutions, in interaction with language-aware teachers" (Droga \& Humphrey, 2003, p. 3).

\section{Principle 3: Pedagogy makes knowledge visible}

Pedagogy is the means for organising knowledge and for making that knowledge visible to students and a visible pedagogy is one in which the teacher controls what is to be learnt and how it is to be learnt, and this is made explicit to students (Joyce \& Feez, 2012; Droga \& Humphrey, 2003). Under this principle, teachers should be more explicit in teaching several aspects, including how language works to make meaning, the text organization, and linguistic forms that characterize different genres. At the beginning of the teaching and learning the teacher controls what is to be learnt and how it is learnt. As the students build their knowledge and skill, the teacher strategically hands over control to the students, varying the level of control and the visibility of the teaching in response to students' needs and capabilities (Martin \& Rose, 2008; Joyce \& Feez, 2012). This explicit teaching, as Rose \& Martin (2012, p. 17) argue, "should be harmonised with students" experience, knowledge and need".

SFL GP also emphasizes the importance of knowledge of grammar, as Derewianka argues:

A knowledge of grammar can help us to critically evaluate our own text and those of others, e.g. identifying points of view; examining how language can be manipulated to achieve certain effects and position the reader in a particular way; knowing how language can be used to construct a particular identity or a particular way of viewing the world (1998, p. 1).

These principles are emphasised in each model of SFL GP and the model used in this study will be delineated below. 


\section{Model of SFL GP}

This study adapted a model of SFL GP from Derewianka as cited in Hertzberg (2012). The model consists of five steps, including building topic knowledge, building text knowledge, guided activities to develop vocabulary and text knowledge, creating a text independently and reflecting on language choices. However, the study modified the model into three steps: building topic knowledge, building text knowledge and independent creation of text as shown in Figure 1.

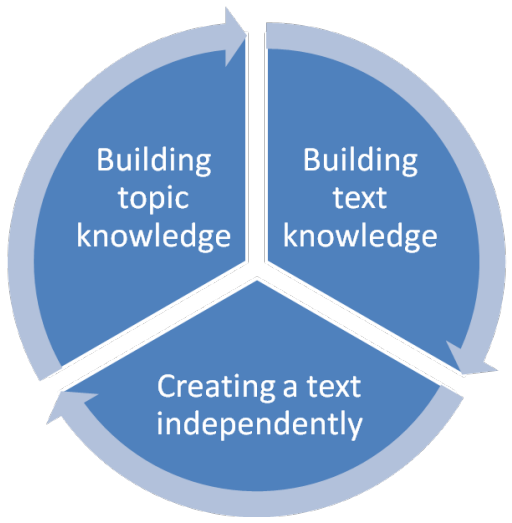

Figure 1: A Model of SFL GP Used in the Study (adapted from Derewianka, in Hertzberg, 2012, p. 115)

The step to do with guided activities to develop vocabulary and text knowledge (Step 3), described by Derewianka (2007), termed Joint Construction in the previous models, to follow Feez (2002), was skipped, as the students were already familiar with the texts in focus and in the interest of time. Moreover, Step 5, reflection on language choices, was incorporated into the step of independent creation of text. Activities conducted in each stage will be outlined in the methodology section.

It is important to note that throughout the stages of SFL GP, especially in EFL contexts, like this study, "there are plenty of opportunities for students to speak, to read and to listen in the students' mother tongue and the target language" (Garcia, 2009, p. 363). 


\section{Text Types in Focus}

As alluded to earlier, this paper will present only samples of Expositions and thus this section will focus on Exposition.

An Exposition is a factual text that requires the writer to adopt a position and argue for it, endeavoring to persuade the reader to accept the proposition (Christie \& Derewianka, 2008; Martin \& Rose, 2008).

The schematic structure of an Exposition includes:

- a Thesis: introduces the issue and the writer's point of view regarding the issue;

- Arguments: presents a series of arguments which support the thesis, containing any factual information, evidence, description or explanation which supports the thesis;

- a Restatement of the Thesis, a stronger and more direct statement of the thesis introduced in the first stage. This stage sums up the position in the light of the arguments presented, reaffirming the general issues under discussion and possibly calling for action (see Feez \& Joyce, in Emilia, 2005, 2010).

An Exposition also usually has several linguistic features, including:

- generalised participants: smoking, junk food, national examination;

- connectives structuring the arguments: Firstly, secondly, thirdly;

- logical connectives: so; or words showing cause and effects (because ...., so ...);

- usually timeless present tense: smoking is dangerous ...;

- variety of process types: action, verbal, mental, relational.

\section{METHOD}

This study used a qualitative case study research design (Yin, 2003; Liamputong, 2009) as it investigates a bounded system - a process of teaching learning that lasted several months and happened in a particular setting (Smeijters and Aasgard, cited in Liamputtong, 2009), that is a writing class in a tertiary EFL context. The study involved 19 Indonesian students, 12 girls and 7 boys, aged between 19 to 21 . They were originally from different parts of Indonesia, especially Java and Sumatera, but mostly from Sundanese ethnic group with bahasa Sunda as their mother tongue, Bahasa Indonesia as their second language and English their foreign language. The class was chosen out of four, 
learning the same subject because the teacher was assigned to teach this class and thus the sampling of the participants can be considered as convenient sampling (Nunan \& Bailey, 2009). From the perspective of classroom observation, this class can be considered a regular class, which was beneficial as it could lead to "a natural and undisturbed lesson" (van Lier, 1988, p. 39).

The teaching program was conducted in one semester, 16 meetings, each of which lasted for 100 minutes, with "the teacher acting as researcher" (Stake, 1995). A field note on what was said and done (van Lier, 1996) by both the teacher and the students was written immediately after each meeting while the researchers' memory was still fresh.

In the first meeting the students were informed of several matters below.

- The teacher, apart from teaching, would do research, implementing the SFL GP, to find out whether this pedagogy could help them improve their writing.

- The students would need to do all activities relevant to the SFL GP and all the work over the course, including their drafts would be submitted.

- Some of students' work would be included in the research report and published in an academic work, but their names would not be disclosed

- The students would be asked to fill in a questionnaire at the end of the course anonymously.

- The course would focus on three genres: Exposition, Discussion and Response to Literary Works. At that time, the students seemed to be aware of those text types, which made the teacher heartened, but as the data will indicate, they still needed a lot of guidance to write a good text.

- The students were free to move to another class if they thought the schedule or activities did not suit them.

Upon the students' agreement, through the signing of a consent form, the class began with an overview of the syllabus and identifying the topic the students would write for their first text, that is, Exposition.

The sequence of the teaching program followed the model of SFL GP explained previously and the work of Hunt (1994), Feez (2002), Martin (2011), Hertzberg (2012), and Joyce \& Feez (2012). The sequence thus consists of three stages, that is, building topic knowledge, building text knowledge, and creating a text independently.

Building topic knowledge aimed to build students' background knowledge about the topic to write. To follow Hunt (1994), activities in this stage included helping students identify the topic they were going to write and what aspects 
would be explored. The students, from the first meeting were assigned to read multiple texts at home and in the classroom. While reading, they were encouraged to take notes on important points regarding the topic. This stage, to follow Martin (2011) and Joyce \& Feez (2012), continued over each teaching cycle, when the students kept adding to their writing more information they gained along the process of writing.

Activities in the building text knowledge stage included: (1) discussion of the social purpose of the genre, i.e. understanding why and in what circumstances an Exposition, a Discussion, and Response to Literary Works were written, and consideration of the register (field, mode and tenor), audiences and desired outcomes from writing a particular text; (2) investigation of texts using the genre in focus to determine how they are organised in stages and the function of each stage, and which particular language features are used (e.g. the use of modality, saying verbs, references to authorities).

The students were also shown how to create a text which is coherent and cohesive globally through the use of higher level Themes, such as macro- and hyper-Themes (Martin, 1992) and multiple Theme pattern, and locally, through the use of clause Themes and the zig-zag, and reiteration Theme patterns (Eggins, 1994, 2004; Martin \& Rose, 2003, 2007; Joyce \& Feez, 2012). This stage primarily involved teacher-led discussion and activities (see Hertzberg, 2012).

At the final stage, creating a text independently, students practised writing a text independently in several drafts. Students undertook to research, to write, edit and publish their own texts, consulting with the teacher and peers and using the understanding of the genre gained in the previous stages. Each draft was given feedback "to help students build awareness, knowledge and strategic competence to develop skills to better monitor their own writing in the future" (Bitchener \& Ferris, 2012, p. 140).

The teaching of Exposition took seven meetings, and Discussion and Response to Literary works 5 and 4 meetings respectively. The teaching of Exposition took longer as it was the first time the students wrote an argumentative text in different drafts. Students' texts were collected for further analyses as students' written texts, as Kress (1985, p. 47) argues "everywhere bear the signs of the struggle to meet the demands of the generic form, the effects and meanings of discourses, and the forms of language in the written mode, and everywhere bear the signs of their achievement in doing so." Moreover, as "texts reveal the meaning and the processes involved in their making" (Kress, 2011 , p. 205), the students' texts also reveal the teaching learning process and 
"constitute one of the most important sources of target situation data in devising an L2 (EFL) writing syllabus" (Hyland, 2003, p. 62). At the end of the teaching program a questionnaire consisting of 10 open-ended questions regarding the program was distributed to all students.

All data were analysed qualitatively over and at the conclusion of the program. Data analysed over the teaching program, including those from observations and students' drafts were used to identify what worked well and what needed improvement in each meeting. Three samples of final draft of each text type, representing low, mid and high achievers were analysed using SFG (Halliday, 1994; Eggins, 1994, 2004; Humphrey, Love, \& Droga, 2011; Humphrey, Droga, \& Feez 2012). SFG provides a powerful analytical tool and constitutes "one of a variety of linguistic approaches that have been well developed in the area of education" (Freebody, 2003, p. 185). Finally, data from the questionnaires were categorised into central themes relevant to the teaching program and then interpreted. A "data source triangulation" (Stake, 1995, p. 112) was conducted, to enhance the validity of the conclusion of the study. In the process of analyses students' real names were removed and changed into pseudonyms

\section{FINDINGS AND DISCUSSION}

\section{Findings}

The results of the study, as will be alluded to later, show that in general the study supports previous research in the Indonesian context (Emilia, 2005, 2010; Emilia, Hermawan, \& Nurhayati, 2008; Emilia et al., 2012) that despite some aspects that still need improvement, SFL GP can help learners succeed in their learning English, especially writing. All activities in SFL GP were found to complement each other and contributed to the students' improved writing ability which can be seen from several aspects below.

The first aspect regards the students' control of the schematic structure and linguistic features of the texts in focus. Students' mastery of the schematic structure of Exposition and Discussion, for example, can be seen in the excerpt below, occurring after building text knowledge of the Discussion.

Student: Mam, at the end of a Discussion, we need to express our opinion?

Lecturer: Yes. So, what is the difference between Exposition and Discussion? 
Student: Discussion presents arguments for and against while Exposition expresses our opinion about something and then we support the opinion with arguments (Observation notes).

The excerpt above shows that building text knowledge could lead to students' good control of the structure of each text to achieve its goal, as suggested by Martin \& Rose (2008), Hertzberg, (2012) and Joyce and Feez (2012). This is supported by data from text analyses (see Table 3), that all texts fulfill the demands of generic form of an Exposition, and its social purpose, "which is the first and foremost task of a writer" (Kress, 1985, p. 46).

The second aspect related to the students' growing capacity to organise their ideas more smoothly, which is the results of all activities in the program, including independent writing stage, where students wrote different drafts with guidance and feedback from the lecturer and peers. The development will be elaborated below.

The first part of the first draft of an Exposition written by a low achiever girl, for example, can be seen in Table 2 .

\section{Table 2. A Sample of the First Part of an Exposition Written by a Low} Achiever

In this decade, everyone have cell phones and many benefits to users, but in fact a lot of negative effects from the use of mobile phones for its users who wrote the online article on http://www.controlyourimpact.com/2008/03/disadvantages-of-cell-phonesnegative-health-effects/, Dr. Agarwal.PhD stated, "Electromagnetic waves alter electric activity of the brain ... ." In this essay I'd like to fully expose the reasons disadvantages of mobile phones."

(Notes: underlined words or expressions are grammatically incorrect)

The text in Table 2 indicates the writer's attempt to build the topic knowledge, shown by the presence of reference and proper name (Dr. Agarwal). However, the writer needed guidance on how to use language to make meaning, and how to "assemble ideas" (Kress, 2003, p. 6), taken from other sources. 
Similar cases depicting students' struggle to organise ideas, and to involve other's voice in their writing through the use of quotations to support arguments can be seen below.

\section{Excerpt 1 (by a low achiever)}

... As written by researcher, Kjel Mild (2008) have found out that cell phones damage key brain cells and could trigger the early onset of Alzheimer's disease (Low achiever)

\section{Excerpt 2 ( by a mid achiever)}

... And also Hanna Papanel et al do a research to USA women and from the research there is no one who refuse the opinion ... (Kontjaraningrat, 1982: 47).

Excerpts 1 and 2 depict the writers' struggle in grammar (underlined words) and incapacity to present ideas taken from the references they read. In both excerpts it is not clear who says what.

This suggests that having a strong background knowledge is important, but it is not sufficient to allow students to write a cohesive and coherent text. This shows that the ability to write is not given and the teacher needs to be more explicit in teaching several aspects, including how language works to make meaning, and linguistic forms that characterise different genres in an apprenticeship to lead to students' capacity to write a good text; Gibbons, 2002; Rose \& Martin, 2012, Derewianka \& Jones, 2012; Joyce \& Feez, 2012). in:

The first drafts students wrote also show some basic grammar mistakes, as

"Those who are support plastic surgery say ...." (Sinta);

"We can easily found that ..." (Toni);

“An electronic devices ..." (Reni).

Finally, the first draft also shows the tendency to write overgeneralisation, as in the first sentence in Table 2: "Everyone have cellphones". This suggests the student's care in writing statements, especially in argumentative writing should be nurtured and explicitly taught (Emilia, 2005).

After several meetings, and several drafts with guidance, feedback and ongoing assessment of and by students, as Hertzberg (2012, p. 115) suggests, 
the students gradually could organise ideas more smoothly, insert quotations properly, and use grammar correctly, as shown in the following examples.

\section{Excerpt 3 (by a low achiever)}

... As written by Kjel Mild (2008) that cell phones damage key brain cells and can trigger the early onset of Alzheimer's disease (Low achiever)

\section{Excerpt 4 (by a low achiever)}

... Firstly, fast food contains too much calories which cause high blood pressure (www.barrackht.school.nsw.edu.au). According to Nasir (2009), when we eat fast food regularly, it will increase ALT (alanine amintransferase) in our body. ... .

\section{Excerpt 5 (by a mid achiever)}

Second, Educational researchers have found that there is a strong correlation between reading and academic success (www.improve-reading-skills.com)... Murahimin said that the success of a city depends on the rate of reading habit of the people there $(2001$, p. 16)

\section{Ecxerpt 6 (by a high achiever)}

Utomo Dananjaya, ... stated that National Examination has ignored the true meaning of student's personality... . This is supported by Sulistyo, the leader of Persatuan Guru Republik Indonesia (Indonesian Teachers Union) ... .

Excerpts 3 to 6 show students' improved grammar and capacity to incorporate other's voice or "otherness" (Kress, 1982) properly in their writing. This capacity to include otherness constitutes "the highest development of students' writing capacity", as Kress (1982, p. 119-120) asserts.

At the end of the first teaching cycle, despite some grammar mistakes still found in some drafts of the students, all Expositions written by the students, as samples in Table 3 show, have all required elements, including Thesis, Arguments and Restatement of Thesis. The texts, in the interest of space, however, cannot be presented completely.

Regarding the grammar mistakes in the students' final drafts, as in the conclusion of Text 1, it is probably fair to say that grammar mistakes do not necessarily indicate the program was not successful. Regarding this, Bitchener \& Ferris (2012, p. 140) argue that "writing courses cannot, and should not, be about helping or requiring students to produce ideal or perfect, error free texts. 
Not only are such goals unrealistic - language and literacy development takes time....".

Table 3. The Schematic Structure of Sample Students' Expositions from Different Levels of Achievement

\begin{tabular}{|c|c|c|c|}
\hline \multirow{3}{*}{$\begin{array}{l}\text { Stages of the } \\
\text { texts }\end{array}$} & \multicolumn{3}{|c|}{ Title and Sample Text } \\
\hline & $\begin{array}{l}\text { Mobile phone } \\
\text { disadvantages }\end{array}$ & $\begin{array}{l}\text { How important is } \\
\text { family planning } \\
\text { program? }\end{array}$ & $\begin{array}{l}\text { National } \\
\text { examination } \\
\text { should be } \\
\text { eliminated. }\end{array}$ \\
\hline & $\begin{array}{l}\text { Text } 1 \text { by a low } \\
\text { achiever }\end{array}$ & $\begin{array}{l}\text { Text } 2 \text { by a mid } \\
\text { achiever }\end{array}$ & $\begin{array}{l}\text { Text } 3 \text { by a high } \\
\text { achiever }\end{array}$ \\
\hline Thesis & $\begin{array}{l}\text { In this decade, many } \\
\text { people have } \\
\text { cellphones. } \\
\text { Cell phones give } \\
\text { many benefits to } \\
\text { users, but I believe } \\
\text { there are a lot of } \\
\text { negative effects } \\
\text { from the use of } \\
\text { mobile phones } \\
\text { [[based on the } \\
\text { arguments below]]. }\end{array}$ & $\begin{array}{l}\text {... I personally believe } \\
\text { that family planning } \\
\text { program is one of the } \\
\text { solutions because it has } \\
\text { so many advantages } \\
\text { below. }\end{array}$ & $\begin{array}{l}\text { I personally agree } \\
\text { with the second } \\
\text { position (that } \\
\text { national } \\
\text { examination } \\
\text { should be banned) } \\
\text { [[based on the } \\
\text { issues [[that are } \\
\text { elaborated from } \\
\text { various points of } \\
\text { view below]]. }\end{array}$ \\
\hline Arguments & $\begin{array}{l}\text { Firstly, the use of } \\
\text { mobile phone can } \\
\text { cause many diseases } \\
\text { and health } \\
\text { problems... . } \\
\text { Secondly, mobile } \\
\text { phone can cause } \\
\text { infertility in man } \\
\text { too, as written by } \\
\text { Derias et al. (2005) } \\
\text { in the conclusion of } \\
\text { 'Growing concern } \\
\text { over the safety of } \\
\text { using cell phones }\end{array}$ & $\begin{array}{l}\text { Firstly, for the mother, } \\
\text { family planning } \\
\text { program will prevent an } \\
\text { unexpected pregnancy. } \\
\text { Parents can decide how } \\
\text { many children they will } \\
\text { have. Family planning } \\
\text { program can also } \\
\text { prevent the mortality } \\
\text { (number of death) of the } \\
\text { mother, if she is not at } \\
\text { her productive age } \\
\text { again. Besides, family } \\
\text { planning program will } \\
\text { keep the mother's health }\end{array}$ & $\begin{array}{l}\text { First, National } \\
\text { Examination is } \\
\text { morally } \\
\text { decreasing the } \\
\text { quality of teachers } \\
\text { and students of } \\
\text { Indonesia } \\
\ldots \\
\text { Second, National } \\
\text { Examination } \\
\text { doesn't agree with } \\
\text { the value of } \\
\text { humanity. } \\
\text { We can see the } \\
\text { background of }\end{array}$ \\
\hline
\end{tabular}




\begin{tabular}{|c|c|c|c|}
\hline \multirow{3}{*}{$\begin{array}{l}\text { Stages of the } \\
\text { texts }\end{array}$} & \multicolumn{3}{|c|}{ Title and Sample Text } \\
\hline & $\begin{array}{l}\text { Mobile phone } \\
\text { disadvantages }\end{array}$ & $\begin{array}{l}\text { How important is } \\
\text { family planning } \\
\text { program? }\end{array}$ & $\begin{array}{l}\text { National } \\
\text { examination } \\
\text { should be } \\
\text { eliminated. }\end{array}$ \\
\hline & $\begin{array}{l}\text { Text } 1 \text { by a low } \\
\text { achiever }\end{array}$ & $\begin{array}{l}\text { Text } 2 \text { by a mid } \\
\text { achiever }\end{array}$ & $\begin{array}{l}\text { Text } 3 \text { by a high } \\
\text { achiever }\end{array}$ \\
\hline & $\begin{array}{l}\text { and male fertility'. } \\
\text {... They say... } \\
\text { “With regard to the } \\
\text { potential damaging } \\
\text { effects on the male } \\
\text { reproductive system, } \\
\text { several studies have } \\
\text { been carried out on } \\
\text { animals. ... } \\
\text { http://www.controly } \\
\underline{\text { ourimpact.com/2008 }} \\
\text { /03/disdvantages-of- } \\
\underline{\text { cell-phones-cause- }} \\
\underline{\text { of-infertility-in- }} \\
\underline{\text { man/... }}\end{array}$ & $\begin{array}{l}\text { (www.puskel.com/3- } \\
\text { manfaat-utama- } \\
\text { program-keluarga- } \\
\text { berencana). } \\
\text { Secondly, for the } \\
\text { children, family } \\
\text { planning program } \\
\text { decreases baby mortality } \\
\text { risk ... } \\
\text { Thirdly, for a father, } \\
\text { family planning } \\
\text { program will minimize } \\
\text { father's responsibilities } \\
\text { because when a family } \\
\text { has many children the } \\
\text { father will need a lot of } \\
\text { efforts to fulfill his } \\
\text { family necessities such } \\
\text { as for nutrition, health, } \\
\text { children's education etc. } \\
\\
\text { Finally, family planning } \\
\text { program has a good } \\
\text { advantage for national } \\
\text { development. A national } \\
\text { development will be a } \\
\text { successful development } \\
\text { when citizens of the } \\
\text { nation are prosperous. }\end{array}$ & $\begin{array}{l}\text { this argument } \\
\text { from what } \\
\text { happened in } 2011 . \\
\ldots \\
\text { Finally, National } \\
\text { Examination is } \\
\text { against the law of } \\
\text { National } \\
\text { Education System } \\
\ldots . \\
\text { Utomo Dananjaya, } \\
\ldots, \text { stated that } \\
\text { National } \\
\text { Examination has } \\
\text { ignored the true } \\
\text { meaning of } \\
\text { student's } \\
\text { personality [[in } \\
\text { which students are } \\
\text { only regarded as } \\
\text { standardized } \\
\text { merchandise]]. }\end{array}$ \\
\hline $\begin{array}{l}\text { Restatement } \\
\text { of Thesis }\end{array}$ & $\begin{array}{l}\text { In conclusion, after } \\
\text { [[looking at those }\end{array}$ & $\begin{array}{l}\text { Based on my } \\
\text { explanation above, I can }\end{array}$ & $\begin{array}{l}\text { As the conclusion, } \\
\text { I dare say }\end{array}$ \\
\hline
\end{tabular}


170 TEFLIN Journal, Volume 26, Number 2, July 2015

\begin{tabular}{|c|c|c|c|}
\hline \multirow{3}{*}{$\begin{array}{c}\text { Stages of the } \\
\text { texts }\end{array}$} & \multicolumn{3}{|c|}{ Title and Sample Text } \\
\hline & $\begin{array}{l}\text { Mobile phone } \\
\text { disadvantages }\end{array}$ & $\begin{array}{l}\text { How important is } \\
\text { family planning } \\
\text { program? }\end{array}$ & $\begin{array}{l}\text { National } \\
\text { examination } \\
\text { should be } \\
\text { eliminated. }\end{array}$ \\
\hline & $\begin{array}{l}\text { Text } 1 \text { by a low } \\
\text { achiever }\end{array}$ & $\begin{array}{l}\text { Text } 2 \text { by a mid } \\
\text { achiever }\end{array}$ & $\begin{array}{l}\text { Text } 3 \text { by a high } \\
\text { achiever }\end{array}$ \\
\hline & $\begin{array}{l}\text { reasons]], } \\
\text { it is obvious that } \\
\text { cellphone cause } \\
\text { negative effects for } \\
\text { its user. People must } \\
\text { reduce the intensity } \\
\text { of the use of mobile } \\
\text { phones and use them } \\
\text { wisely. } \\
\text { Note: underlined } \\
\text { words indicate } \\
\text { incorrect grammar. }\end{array}$ & $\begin{array}{l}\text { conclude that family } \\
\text { planning program is } \\
\text { really important for us } \\
\text { because it has a lot of } \\
\text { advantages which will } \\
\text { make us more } \\
\text { comfortable in our life. } \\
\text {... }\end{array}$ & $\begin{array}{l}\text { that National } \\
\text { Examination is not } \\
\text { effective for } \\
\text { [[building our } \\
\text { national } \\
\text { education]], } \\
\text { and so that it must } \\
\text { be eliminated and } \\
\text { changed by a new } \\
\text { system [[that } \\
\text { supports the idea } \\
\text { of the philosophy } \\
\text { of education in } \\
\text { Indonesia]]. }\end{array}$ \\
\hline
\end{tabular}

With respect to the linguistic features, students' strong writing capacity can be seen from the three systems of SFG, as will be presented below.

First, from the Theme system, linguistic resources seem to be efficiently used to create texts which develop smoothly not only locally but also globally. This is evidenced by the employment of higher-level Themes (macro- and hyper-Themes) and "multiple" (Eggins, 1994, 2004) Theme development (see Table 4).

Table 4. The Multiple Theme Patterns in Samples of Exposition

\section{In Text 1}

... but I believe ...

there are a lot of negative fects from the use of mobile phones ... [ [based on the ar-<smiles>CC(C)COC(C)C</smiles>

Firstly, the tre of mobile phone can cause, many diseases and health problems... .

Secondly, mobile phone can cause infertility in man too, as written by Derias et al state 
(2005) in the conclusion of 'Growing concern over the safety of using cell phones and male fertility'.

\section{In Text 2}

I personally believe that family planning program is one of the solutions because it has so many advantages below.

First, for the mother, family planning program will preventrexpeeted pregnancy. Parents can decide how many children they will have. Family planning program can also prevent the mortality (number of deathe of thother, if she is not at her productive age again. Besides, family planning progtam will keep the mother's health (www.puskel.com/3-mantaat-utma-program-keluarga-berencana

Second, for thechildren, family planting program decreases baby mortality risk ...

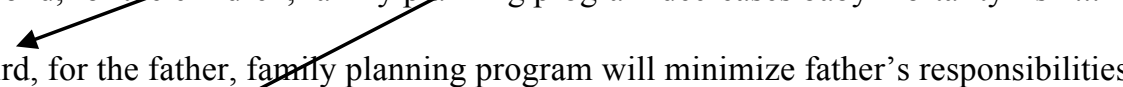

Third, for the father, family planning program will minimize father's responsibilities because when a fantily has many children the father will need a lot of efforts to fulfill his family neeessities such as for nutrition, health, children's education etc.

Finally, family planning program has a good advantage for national development. A national development will be a successful development when citizens of the nation are prosperous.

\section{In Text 3}

I personally agree with the second position (that national examination should be banned) [[based on the issues [[that are elaborated from various points of view below]] ]]. First, National Examilition is morally decreasing the quality of teachers and students of Indonesia...

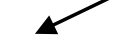

Second Xational Examination doesn't agree with the value of humanity.

Finally, National Examination is against the law of National Education ... 
All texts in Table 4 successfully use a macro-Theme, which is the introductory paragraph of school rhetoric (Martin, 1992, p. 437), and this allows the reader to predict the text overall development. All texts also efficiently employ hyper-Themes (the topic sentence in each paragraph) as the opening generalisation in a paragraph which predicts the pattern of clause Themes and elaboration (Martin, 1992; Coffin, 1997). The texts also manage to exploit enumerations (three, first, second and third), a textual strategy which works at the text level.

Moreover, still from the Theme system, the topic sentence of the conclusion indicates that the stage refers back to points presented and draws conclusions from what has been described in the previous stages (... after looking at those reasons; Based on my explanation above; as the conclusion ...). Accordingly, the stage successfully functions as "macro-New" (Martin, 2002), which looks back, gathering up the meanings which have accumulated to elaborate a text field.

The structure of students' texts, for example, Text 1, to follow Coffin (1997; see also Emilia, 2010) can be described in Figure 2.

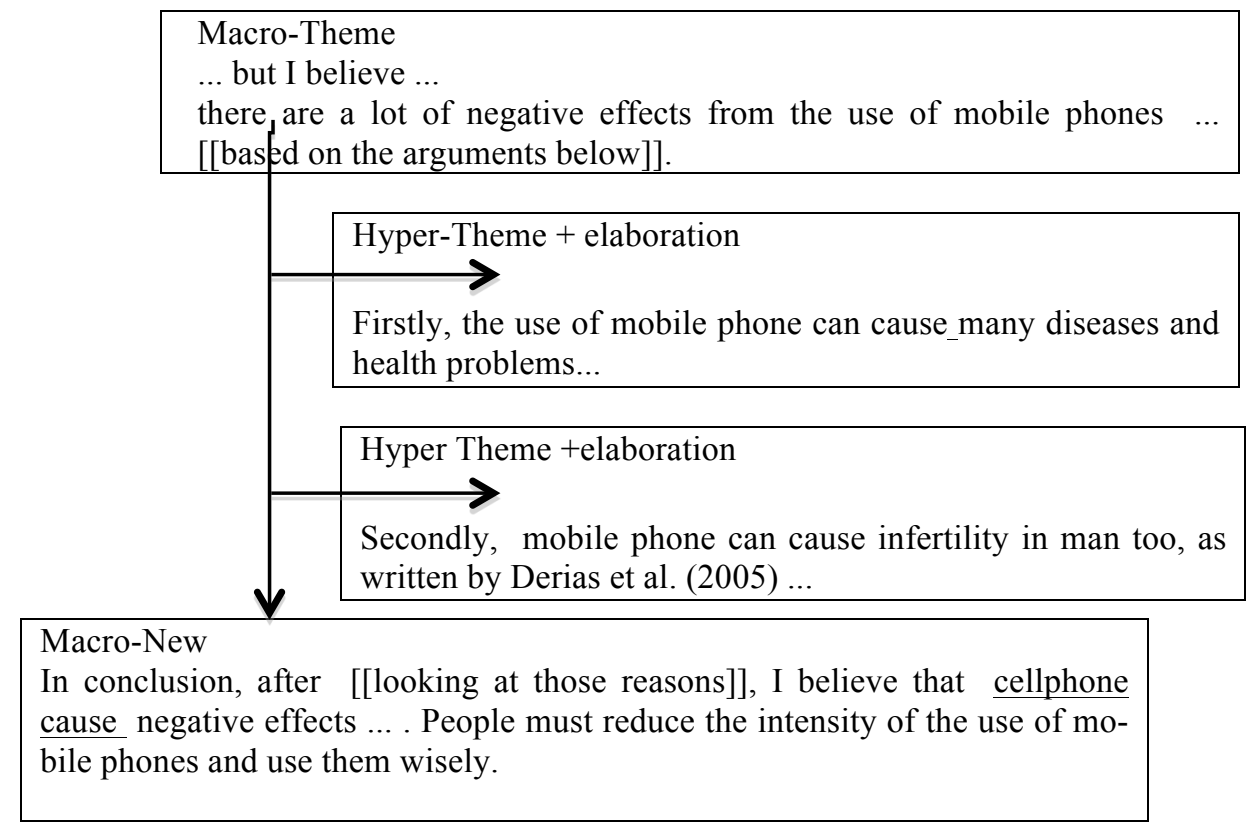

Figure 2: The Structure of Exposition about Cellphone 
From the schematic structure above, Text 1 (see also Texts 2 and 3 ) shows the writer's good control of the demands of the generic form of an Exposition, to achieve the purpose of the genre. The schematic structure indicates that the text is "interactive", meaning that it involves the management of the flow of information and thus serves to guide readers through the content of the text (Thompson, 2001), with the elements overtly marked by appropriate Themes. The text also projects forward through the employment of macro-, hyper- and clause-Themes and projects back through the use of macro-New, as it unfolds. This results in a "textured sandwich" (Martin, 1992, p. 456; see also Emilia, 2014), which suggests real improvement in writing and an instance of indications of good writing, relevant to the genre. Overall, the schematic structure of Text 1 suggests that the text is now on its way to becoming an effective piece of an Exposition.

Other Theme progressions, the zig-zag and reiteration patterns (Eggins, 1994, 2004) are also employed, as in the following examples.

\section{The zig-zag pattern:}

In Text 2:

Family planning program can also prevent the mortality (number of death) of the mother,

if she is not at her productive age again ...

Finally, family planning program has a good advantage for national development.

A national development will be a successful development ... .

\section{The Theme-reiteration pattern:}

In Text 2

I can conclude

that family planning program is really important for us

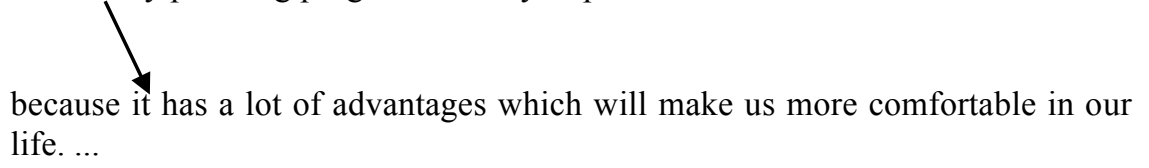

In Text 3

As the conclusion, I dare say 
that National Examination is no longer effective for [[building our national education]],

and so that it must be eliminated.

Overall, Theme choices suggest that the texts are writerly as they foreground items more specifically to do with the topic under consideration, evidenced by the topic-based Theme choices above.

Second, from the Transitivity system, the texts successfully exploit different linguistic sources, including types of processes, and conspicuous is the presence of verbal processes (states, say). The employment of such processes in reporting or projecting clauses signals the writers' capacity to include otherness, the significance of which has been mentioned previously, and the presence of "discourse representation" (Fairclough, in Emilia, 2005, p. 194), which is a form of intertextuality. Moreover, the texts employ more abstraction and technical terms about the topic (family planning, infertility, baby mortality, national examination, law on education) and proper names (Derias et al, Utomo Dananjaya) to create more written-like and intertextual texts, to build sound and credible arguments. Nominalisations, such as infertility, mortality, constitute "the most significant feature of students' development from more oral language to a more academic register" (Colombi, 2002, p. 77). Moreover, the use of circumstances (in Indonesia, in 2011) also helps give clearer information on the topic.

Finally, from the Mood system, the texts efficiently use various linguistic resources to create effective communication with an audience or the reader, which is an essential source of evidence of sophistication in both thought and capacity in using "the right language in the right way within particular discursive settings" (Gee cited in Emilia, 2005, p. 162). The use of declarative mood in the texts is relevant to the purpose of, that is, to persuade people through providing information regarding the topic. Moreover, successful use of modality, both modalisation (can, will) and strong modulation (must), realised metaphorically, either subjectively oriented, as in I believe, or objectively oriented as in "It is obvious that ..." gives a wider impact on the reader. Finally the use of first person pronoun at the beginning and the end of the text is also appropriate, relevant to the purpose of the text, to present the writer's stance about the topic. The use of first person pronoun I, in the last part of the text, as in "I dare say" in Text 3, shows the writer's strong personal opinion, and this is appropri- 
ate after more impersonal and factual cases have been established in the Arguments stage. The absence of first person pronouns in the Arguments stage "does not make the writer lose his personal voice" and the presence of first person pronoun at the last stage, "even makes the text more powerful", as Mc McCarthy and Carter (1994) argue (in Emilia, 2005, p. 162).

As to the students' opinions on the teaching program, data from the questionnaire support the data from observations and text analyses above, as represented by the statements from the students (in pseudonyms) below.

"I think my writing skill increases this semester and I know how to write a text well" (Selly).

"At first I thought it was good enough, but after I got concepts from my lecturer, I didn't have good writing. However, after this course, I think my writing improves" (Tedi).

Some students were also aware of the relevance between writing and other language skills, such as reading and speaking. Rita and Toni, for example, explained:

"Writing in this context is important to develop other aspects such as reading and speaking (Rita).

"The course polishes many skills such as reading, grammar and of course writing skills" (Toni).

Regarding activities in the program, students' opinions coincide with the points from genre theorists (Gibbons, 2002; Derewianka \& Jones, 2012; Joyce \& Feez, 2012; Rose \& White, 2012) and will be outlined below.

The first activity, building topic knowledge, was considered important by the students to help them improve not only writing, but also reading. Some students pointed out:

"When the lecturer asked us to build knowledge or to read about the topic that we are going to write, we felt that we understood better about the topic that we were going to write and it made us easier to write" (Selly).

"Learning writing in this semester makes me learn that writing is important and we must have good knowledge to write a text. We must read" (Toni). 
One point deserves a brief mention regarding building topic knowledge, that is that it allowed students to be more diligent in reading, as mentioned by Fachry below.

"It made us diligent. It encourages us to read and to build our knowledge." (Fachry).

The second activity, that is building text knowledge, was also viewed valuable by the students, although they already learnt those text types in high school. Tuti and Sinta said

"I really support this because probably some students forget those schematic structures and it's good" (Tuti).

"Knowing schematic structure helps me to write systematically" (Sinta).

What Tuti and Sinta said confirms the suggestion that building text knowledge is helpful to lead to students' mastery of the schematic structure of a text, which is the first task of a writer, as mentioned above.

The third activity, writing different drafts with guidance and feedback from the lecturer was considered the most important activity in the program, as can be seen from the following verbalisations.

"I like when I have to write individually, so I can learn how to make a good text and then the quality of the feedback given is very helpful for me in improving my writing skills" (Temmy).

"What I like best from this course is the way we revise our draft to make a good text" (Sandra).

Temmy's and Sandra's statements above suggest the value of teaching writing as a process, when the students write different drafts to lead to students' awareness that writing is not a one shot activity (Gibbons, 2002; Bitchener \& Ferris, 2012). Temmy and Sandra's statements also suggest the significance of feedback and guidance to help students create a good text. Writing different drafts might not have significantly affected the quality of the text if the students did not get appropriate feedback and guidance from the teacher. 
Regarding the teaching of grammar at any stage, when the students needed it, the students also expressed positive responses below.

"What I also like best in this course is when the lecturer gave new thing about grammar to us, especially in making Exposition text (Tuti).

"What I like best in this course is when I could correct my grammar in my assignment for other courses"(Sinta).

Tuti's and Sinta's statements above confirm the imporance of the teaching of grammar explicitly in context as suggested by SFL GP (see Gibbons, 2002). Sinta's statement also confirms the value of knowledge of grammar which can help us to critically evaluate our own text and those of others, as Derewianka (1998) argues. Sinta's statement also suggests that to some extent, the aim of feedback, to help students develop skills to better monitor their own writing, as Bitchener \& Ferris (2012) argue, has been achieved.

Another aspect worth a brief mention is about sharing with peers, which can help clarify students' ideas, as said by Tuti:

"There are times when I don't get the idea. After asking my friends, it's clear eventually" (Tuti).

However, regarding feedback from peers, it was found in this study that not all students could give quality feedback. Some students tended to give feedback superficially and this supports previous research (Emilia, 2005) that correcting the students' writing should be done carefully, as it possibly makes the students learn very little in the process. So, this warrants further research on when, who and how to use feedback.

Finally, when asked about what aspects that should be improved, some students said:

"So far, I really like this course, so there is nothing to improve" (Sinta).

"I don't think there is somtehing that should be improved for this course because I enjoyed the course so far" (Selly).

"As SBY [the President fo Indonesia] says "lanjutkan" [Continue]". 
However, some other students gave a suggestion about the teaching of grammar which they thought was still insufficient and the time of the course which should have been made longer. The occurence of grammar mistakes in the final draft, written by a low achiever in particular, indicates that indeed more efforts should have been made to help students develop their grammar.

\section{CONCLUSIONS AND SUGGESTIONS}

This article has presented the outcome of a study aiming to investigate whether SFL GP could help develop students' ability in writing argumentative texts in a tertiary EFL context in Indonesia and to find out students' responses to the teaching program using SFL GP. The study confirms previous research that SFL GP can generally help students develop their writing and other aspects, like reading, speaking and grammar. All stages in SFL GP were of great significance for the students' writing development and students' responses to each activity were positive although some improvements to do with the teaching of grammar and peer correction should be made. It is thus recommended that SFL GP be implemented in other subject areas and contexts, in Indonesia and other EFL or ESL contexts in other countries in a longer period of time. Further research may also focus on the role of peer feedback in the development of students' texts and the teaching of grammar.

\section{REFERENCES}

Bitchener, J., \& Ferris, D. R. (2012). Written corrective feedback in second language acquisition and writing. New York: Routledge.

Callaghan, M., Knapp, P., \& Noble, G. (1993). Genre in practice. In B. Cope \& M. Kalantzis, (Eds.), The powers of literacy: A genre approach to teaching writing (pp.179-202). London: The Falmer Press.

Christie, F. (2012). Language education throughout the school years: A functional perspective. Malden USA and West Sussex UK: WileyBlackwell.

Christie, F., \& Derewianka, B. (2008). School discourse. London: Continuum.

Coffin, C. (1997). Constructing and giving value to the past: An investigation into secondary school history. In F. Christie \& J. R. Martin (Eds.), Genre 
and institution: Social processes in the workplace and school (p.196-230). London: Continuum.

Colombi, C. M. (2002). Academic language development in Latino students' writing in Spanish. In M. J. Scleppegrell \& M. C. Colombi (Eds.), Developing advanced literacy in first and second languages. Meaning with power (pp. 67-86). Mahwah, N.J: Lawrence Erlbaum Associates, Inc.

Derewianka, B. (1998). A grammar companion for primary teachers. Newtown: PETA.

Derewianka, B., \& Jones, P. (2012). Teaching language in context. Melbourne: Oxford University Press.

Droga, L., \& Humphrey, S. (2003). Grammar and meaning. An introduction for primary teachers. Berry, NSW: Target Texts.

Eggins, S. (1994). An introduction to systemic functional linguistics. London: Printer Publishers, Ltd.

Eggins, S. (2004). An introduction to systemic functional linguistics. (2nd Edition). London: Printer Publishers, Ltd.

Emilia, E. (2005). A critical genre-based approach to teaching academic writing in a tertiary EFL context in Indonesia. Volume 1. (Doctoral dissertation, University of Melbourne, Melbourne, Australia).

Emilia, E. (2010). Teaching writing: Developing critical learners. Bandung: Rizqy Press.

Emilia, E. (2011). Pendekatan genre-based: Petunjuk untuk guru. [Genrebased approach: Guidelines for teachers). Bandung: Rizqy Press.

Emilia, E. (2014). Introducing functional grammar. Bandung: Pustaka Jaya.

Emilia, E., Hermawan, B., \& Nurhayati, D. T. (2008). A genre-based approach and the 2006 curriculum of English: Action research in a state junior high school in Bandung, West Java, Indonesia. A research report, submitted to the English Department, Indonesia University of Education.

Emilia, E., Christie, F., \& Humphrey, S. (2012, December). Indonesian and Australian collaboration in the implementation of genre pedagogy for teaching English as a foreign language in Indonesia. Paper presented in 
the third WERA (World Education Researchers Association) focal meeting in Sydney, Australia.

Feez, S. (2002). Heritage and innovation in second language education. In A. M. Johns (Ed.), Genre in the classroom (pp. 43-69). Mahwah, New Jersey: Lawrence Erlbaum Associates, Publishers

Freebody, P. (2003). Qualitative research in education: Interaction and practice. London: SAGE Publications.

Garcia, O. (2009). Bilingual education in the 21st century: A global perspective. West Sussex: Blackwell Publishing.

Gibbons, P. (2002). Scaffolding language and scaffolding learning: Teaching second language learners in the mainstream classroom. Portsmouth, $\mathrm{NH}$ : Heinemann.

Halliday, M. A. K. (1994). Introduction to functional grammar. (2nd Edition). London: Continuum.

Hertzberg, M. (2012). Teaching English language learners in mainstream classes. Newtown, NSW: PETAA (Primary English Teacher Association Australia).

Humphrey, S., Love, K., \& Droga, L. (2011). Working grammar. An introduction for secondary English teachers. Sydney: Pearson Australia.

Humphrey, S., Droga, L., \& Feez, S. (2012). Grammar and meaning. Newtowm: PETAA.

Hunt, I. (1994). Successful joint construction: In Pen. No. 96. Newtown, NSW: Primary English Teaching Association.

Hyland, K. (2003). Second language writing. Cambridge: Cambridge University Press.

Indonesian Ministry of National Education (2004). The 2004 curriculum: Competence standards: English for senior high schools. Jakarta: Indonesian Ministry of National Education.

Joyce, de Silva. H., \& Feez, S. (2012). Text-based language literacy Education: Programming and methodology. Putney, NSW: Phoenix Education. 
Kress, G. (1982). Learning to write. London: Routledge and Kegan Paul.

Kress, G. (1985). Linguistic processes in sociocultural practice. Melbourne: Deakin University.

Kress, G. (2003). Literacy in the new media age. London: Routledge.

Kress, G. (2011). Discourse analysis and education: A multimodal semiotic approach. In R. Rogers (Ed.). An introduction to critical discourse analysis in education (pp. 205-226). (2nd Edition). New York: Routledge.

Liamputtong. P. (2009). Qualitative research methods. Third Edition. Melbourne: Oxford University Press.

Macken-Horarik, M. (2002). Something to shoot for. In A. M. Johns (Ed.), Genre in the classroom (p. 17-42). Mahwah, New Jersey: Lawrence Erlbaum Associates, Publishers.

Martin, J. R. (1992). English text. System and structure. Amsterdam: John Benjamin's Publishing Company.

Martin, J. R. (2002). Writing history: Construing time and value in discourse of the past. In M. J. Schleppegrell \& M. C. Colombi (Eds.), Developing advanced literacy in first and second languages: Meaning with power (pp. 87-118). Mahwah, N.J: Lawrence Erlbaum Associates, Inc.

Martin, J. R. (2011). Bridging troubled waters: Interdisciplinarity and what makes it stick. In F. Christie \& K. Maton (Eds.), Disciplinarity: Functional linguistic and sociological perspectives (p. 35-61). London: Continuum.

Martin, J. R, \& Rose, D. (2003). Working with discourse. Meaning beyond the clause. London: Continuum.

Martin, J. R., \& Rose, D. (2007). Working with discourse. Meaning beyond the clause. (2nd Edition). London: Continuum.

Martin, J. R., \& Rose, D. (2008). Genre relations: Mapping culture. London: Equinox.

McDonald, L. (2013). A literature companion for teachers. Newtown: PETAA. 
182 TEFLIN Journal, Volume 26, Number 2, July 2015

Nunan, D., \& Bailey, K. M. (2009). Exploring second language classroom research. Boston: Heinle Cengage Learning.

Rose, D., \& Martin, J. (2012). Learning to write, reading to learn: Genre, knowledge, and pedagogy in the sydney school. Sheffield: Equinox.

Rowsell, J. (2013). Working with multimodality: Rethinking literacy in a digital age. London: Routledge.

Stake, R. E. (1995). The art of case study research. Thousand Oaks: SAGE Publications.

Thompson, G. (2001). Interaction in academic writing: Learning to argue with the reader. Applied Linguistics, 22(1), 58-78.

van Lier, L. (1988). The classroom and the language learner. Essex: Longman Group Limited.

van Lier, L. (1996). Interaction in the language curriculum. Awareness, autonomy and authenticity. Essex: Longman Group Limited.

Yin, R. K. (2003). Applications of case study research (2nd Edition). Newbury Park: SAGE Publications. 